\title{
PLASMA-CHEMICAL METHODS FOR CONTROL OF BIOTIC CONTAMINANTS
}

\author{
G.V.Taran ${ }^{1}$ V.A. Breslavets ${ }^{2}$, A.A. Zamuriev ${ }^{1}$, M.O. Yaroshenko ${ }^{2}$, P.O. Opalev ${ }^{1}$, \\ O.V. Maiboroda ${ }^{2}$ \\ ${ }^{1}$ National Science Center “Kharkov Institute of Physics and Technology”, Kharkiv, Ukraine; \\ ${ }^{2}$ National Scientific Center "Institute of Experimental and Clinical Veterinary Medicine”, \\ Kharkiv, Ukraine
}

The possibility and effectiveness of control of biotic contaminants (bacteria, micromycetes) with ozone and air activated by the plasma chemical reactor were studied as an alternative to the chemical methods of treatment using the model of hatching eggs. It was shown that as a result of the egg shell ozone treatment, bacterial contamination decreased by 3083 times after four days of treatment, and the level of microbiota decreased by 2.6 times after five days of treatment. As a result of the egg shell air treatment, bacterial contamination decreased by 30.56 times after three days of treatment, and the level of contamination with microscopic fungi decreased by 6.9 times on the fifth day of treatment. As the amount of $\mathrm{OH}$ radicals in the activated air increased, the level of bacterial culture decreased by 60 times on the third day of treatment, and the level of egg shell contamination with microscopic fungi decreased by 7.2 times on the fifth day of treatment.

PACS: 52.75.-d, 52.77.-j, 52.90. +z

\section{INTRODUCTION}

Low-temperature plasma is now widely used to solve not only a variaety of scientific issues, but also specific production tasks. The most attractive aspects of its application are related to the fact that no liquid solutions are required for plasma processes (i.e. plasma processes are potentially environmentally-friendly) in comparison with the traditional chemical and technological processes. Also, plasma processes are more energy efficient. Physical and chemical activities of plasma have been known for more than 100 years. However, the systematic extensive studies on chemical reactions under such conditions began only in the late 50 s after significant advances in plasma physics and the development of high-voltage equipment [1].

The main feature of plasma-chemical processes is that many reactive particles, such as excited molecules, electrons, atoms, atomic and molecular ions, free radicals (some of these particles can be formed only in plasma), which are responsible for the new types of chemical reactions, are formed in plasma in much higher concentrations than under normal conditions of chemical reactions. Plasma-chemical reactions, as a rule, are multichannel processes, due to which the whole variety of experimental reactions is determined in low-temperature plasma. By changing the conditions of plasma generation and regulation of its composition, reactions can be directed through one or another channel [2].

One of the most promising types of gas discharge for effective implementation of plasma-chemical processes is a barrierless discharge which occurs in sharply inhomogeneous electric fields and is characterized by a diffuse glow in the discharge gap. This type of discharge is characterized by ionization propagation over the entire discharge gap, which makes it possible to obtain large amounts of weakly ionized gas at atmospheric pressure [3].

Taking into consideration that ecological balance is violated in myco-and microcenoses, photooxidant concentration is increased in the atmosphere (air pollution), resistance to phytopathogens is reduced and the use of fertilizers and pesticides (fungicides, insecticides, herbicides) is poorly balanced, the issue of environmental 198 pollution and contamination of feed substrates with the spores of microscopic fungi becomes more acute every year [4 - 7].

It is known that over 25 species of micromycets of such genera as Aspergillus, Penicillium, Mucor, Fusarium, Rhizopus are the permanent representatives of microbiota which is not only responsible for crop damage, but also for respiratory and alimentary mycoses in farm animals and poultry as a result of its growth in the mucous membranes while getting into the living organism with air or feed [5].

The use of chemicals for disinfection is extremely widespread. Today, there is a large number of disinfectants which include such active ingredients as halogens, alcohols, peroxides, phenols, quaternary ammonium compounds, aldehydes, tertiary amines, acids.

With all the variety of disinfectants, the number of components included in their composition is very limited. Each of these components has a specific spectrum of antimicrobial activity, which is responsible for the effectiveness of the disinfectant $[8,9]$.

The main disinfectants have significant drawbacks: multistage disinfection process, high cost of reagents, accumulation of environmentally destructive residuals from exhausted solutions, resistance to the disinfectants being used etc. $[10,11]$.

Therefore, the use of the plasma-chemical control methods in poultry farming is of current interest as an alternative to the use of chemical disinfectants.

Based on the abovementioned, the main task was to study the plasma-chemical methods for controlling the contaminants of biotic origin (bacteria, micromycetes) using the model of hatching eggs.

\section{MATERIAL AND METHOD}

To study the plasma-chemical methods for biotic contamination control, the object under study (the shell surface of hatching chicken eggs) was placed into the test chamber and treated with ozone and air activated by the plasma-chemical reactor.

The studies were conducted using two specially designed and manufactured experimental stands. 
The first experimental stand included such functional units as the air compressor "Secoh sangyo" (Japan) with the capacity up to $50 \mathrm{l} / \mathrm{min}$ and the maximum pressure up to $12.7 \mathrm{kPa}$, the gas flow meter (RM-4 GU3), the laboratory ozone generator "Ozone-agro 1L", the ozone monitor "Teledyne instruments" (USA) $454 \mathrm{H}$ with the measuring range of $0.1 \ldots 100 \mathrm{~g} / \mathrm{m}^{3}$, test chamber for samples and ozone destructor (Fig. 1).
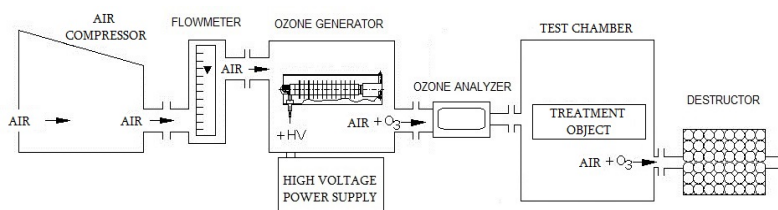

Fig. 1. Block diagram for the first experimental stand

At the first stage of the experiment, the egg shell was treated with ozone in the test chamber $\left(0.504 \mathrm{~g} \mathrm{O}_{3}\right.$ passed through the $0.21 \mathrm{~m}^{3}$ test chamber every 24 hours of ozone generator operation).

The second experimental stand included the following units: a specially designed plasma-chemical reactor equipped with air fan and high-voltage DC power supply unit having the maximum voltage of $10 \mathrm{kV}$ and the maximum load current of $10 \mathrm{~mA}$, test chamber with hatching egg samples placed in it, water container (Fig. 2).

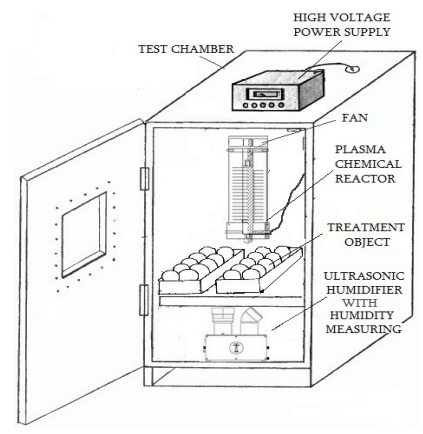

Fig. 2. Block diagram for the second experimental stand
The automatic incubator "INKI-220S" of $265 \mathrm{dm}^{3}$ was used as a test chamber.

While determining bacterial contamination of chicken eggs, each egg shell was swabbed with sterile cotton buds. After this, the swabs were placed into the nutrient broth and then cultivated in such growth media as blood agar, SS agar and Endo agar, which were prepared in accordance with the manufacturer's instructions. Bacterial isolates were identified by analyzing their cultural, morphological (macro- and microscopy) and biochemical characteristics. Namely, the macroscopic morphology was characterized by size, shape, contour, color and changes in different media. Bacteria were stained by the Gram method and examined via light microscopy using an $100 \mathrm{X}$ immersion objective. Biochemical tests were carried out using the generally accepted list of parameters, including coagulase, catalase, oxidase and IMVC [12 - 15].

The level of egg shell contamination with microscopic fungi in the test chamber was determined for the three stages of the experiment by collecting the wipe samples from the egg shell after 72, 96, and 120 hours of treatment in triplicate from each experimental group. After this, serial dilutions (1:1000 was considered as a working dilution) were prepared, the Czapek-Dox agar and wort agar were sown in Petri dishes with dense growth media at the temperature of $(27.0 \pm 0.5) \mathrm{C}^{\circ}$. Inoculation efficiency was determined and micromycets were identified on days $3,5,7$, and $10[5,6,9]$.

\section{EXPERIMENTAL RESULTS}

While determining the effect of ozone treatment on microbiological contamination in the egg shell, the following results were obtained (Table 1).

The total bacterial contamination (see Table 1) in the egg shell $\left(\mathrm{CFU} / \mathrm{cm}^{3}\right)$ decreased by 102.8 times after three days of ozone treatment, and by 3083 times after four days of ozone treatment.

Table 1

The level of bacterial egg shell contamination after ozone treatment

\begin{tabular}{|c|c|c|}
\hline Timing of sample collection & Modes of ozone generator operation & $\begin{array}{c}\text { Total bacterial contamination } \\
\mathrm{CFU} / \mathrm{cm}^{3}\end{array}$ \\
\hline Before treatment, control sample & - & $3.7 \cdot 10^{7}$ \\
\hline Three days of treatment & $\begin{array}{c}\text { Amount of } \mathrm{O}_{3} \text { passing through the test } \\
\text { chamber }-1.512 \mathrm{~g}\end{array}$ & $3.6 \cdot 10^{5}$ \\
\hline Four days of treatment & $\begin{array}{c}\text { Amount of } \mathrm{O}_{3} \text { passing through the test } \\
\text { chamber }-2.016 \mathrm{~g}\end{array}$ & $1.2 \cdot 10^{4}$ \\
\hline Five days of treatment & $\begin{array}{c}\text { Amount of } \mathrm{O}_{3} \text { passing through the test } \\
\text { chamber }-2.520 \mathrm{~g}\end{array}$ & No growth of microorganisms \\
\hline
\end{tabular}

The most effective was ozone treatment for five days - the growth of microorganisms was absolutely absent; i.e. ozone has shown its bactericidal properties.

When studying the effect of ozone treatment on the egg shell background mycobiota, the results presented in Table 2 were obtained.

In accordance with the obtained results (see Table 2), ozone treatment for five days was the most effective. The level of contamination decreased by 2.6 times (contamination level of the control sample was
$0.775 \times 10^{4}$, on the fifth day of the experiment $0.300 \times 10^{4}$ spores per $1 \mathrm{~cm}^{3}$ of dilution).

Mycobiota composition in the control sample was represented by such species as Rhizopus mycrosporus, Aspergillus fumigatus, Alternaria alternata, Penicillium lanosum, Mycelia sterilia, and in the experiment it was represented by Rhizopus mycrosporus, Penicillium lanosum, Alternaria alternata, Mycelia sterilia. It is obvious that ozone treatment contributed to the growth inhibition of Aspergillus fumigatus, that is potentially toxic and mycosis-causing species. 
The level of egg shell contamination with microscopic fungi after ozone treatment

\begin{tabular}{|c|c|c|}
\hline $\begin{array}{c}\text { Timing of sample } \\
\text { collection }\end{array}$ & $\begin{array}{c}\text { Modes of ozone generator } \\
\text { operation }\end{array}$ & $\begin{array}{c}\text { Species and actual level of contamination } \\
\text { (spores per } 1 \mathrm{~cm}^{3} \text { of dilution)* }\end{array}$ \\
\hline $\begin{array}{c}\text { Before treatment, } \\
\text { control sample }\end{array}$ & - & $\begin{array}{c}\text { Rhizopus microsporus, Aspergillus fumigatus, } \\
\text { Alternaria alternata, Penicillium lanosum, Mycelia sterilia. } \\
\text { Contamination level }-0.775 \cdot 10^{4} \text { spores }\end{array}$ \\
\hline $\begin{array}{c}\text { Three days } \\
\text { of treatment }\end{array}$ & $\begin{array}{c}\text { Amount of } \mathrm{O}_{3} \text { passing through } \\
\text { the test chamber }-1.512 \mathrm{~g}\end{array}$ & $\begin{array}{c}\text { Rhizopus microsporus, Alternaria alternata, Penicilli- } \\
\text { um lanosum, Aspergillus fumigatus, Cladosporium spp. } \\
\text { Contamination level }-0.650 \cdot 10^{4} \text { spores }\end{array}$ \\
\hline $\begin{array}{c}\text { Four days } \\
\text { of treatment }\end{array}$ & $\begin{array}{c}\text { Amount of } \mathrm{O}_{3} \text { passing through } \\
\text { the test chamber }-2.016 \mathrm{~g}\end{array}$ & $\begin{array}{c}\text { Aspergillus fumigatus, Rhizopus microsporus, Penicillium } \\
\text { pallidum, Aspergillus proliferans, Penicillium lanosum, } \\
\text { Penicillium casei, yeast-like fungi. } \\
\text { Contamination level }-0.575 \cdot 10^{4} \text { spores }\end{array}$ \\
\hline $\begin{array}{c}\text { Five days } \\
\text { of treatment }\end{array}$ & $\begin{array}{c}\text { Amount of } \mathrm{O}_{3} \text { passing through } \\
\text { the test chamber }-2.520 \mathrm{~g}\end{array}$ & $\begin{array}{c}\text { Rhizopus microsporus, Penicillium lanosum, } \\
\text { Alternaria alternata, Mycelia sterilia. } \\
\text { Contamination level }-0.300 \cdot 10^{4} \text { spores }\end{array}$ \\
\hline
\end{tabular}

The next stage of the experiment was to study the effect of the egg shell treatment with air activated by the barrierless discharge on the contamination level and the species of biotic contaminants (bacteria, micromycetes).

When air treatment was performed, it was found that the level of contamination decreased to $3.6 \times 10^{4} \mathrm{CFU} / \mathrm{cm}^{3}$ after three days of treatment, while the total bacterial contamination was $1.1 \cdot 10^{6} \mathrm{CFU} / \mathrm{cm}^{3}$ prior to the treatment. I.e. bacterial contamination decreased by 30.56 times, and after four days of microbial growth, no contamination was detected (Table 3).

The level of bacterial contamination in the egg shell treated with air activated by the plasma chemical reactor

\begin{tabular}{|c|c|c|}
\hline $\begin{array}{l}\text { Timing of sample } \\
\text { collection }\end{array}$ & $\begin{array}{l}\text { Operation mode of plasma chemical } \\
\text { reactor }\end{array}$ & $\begin{array}{c}\text { Total bacterial contamination } \\
\mathrm{CFU} / \mathrm{cm}^{3}\end{array}$ \\
\hline Before treatment, control sample & - & $1.1 \cdot 10^{6}$ \\
\hline Three days of treatment & Discharge power $-190 \mathrm{~W} \cdot \mathrm{h}$ & $3.6 \cdot 10^{4}$ \\
\hline Four days of treatment & Discharge power $-380 \mathrm{~W} \cdot \mathrm{h}$ & No growth of microorganisms \\
\hline Five days of treatment & Discharge power $-570 \mathrm{~W} \cdot \mathrm{h}$ & No growth of microorganisms \\
\hline
\end{tabular}

After the test chamber was treated with air activated micromycete contamination was changed (see Table 4). by the barrierless discharge, the level of the egg shell

The level of contamination with microscopic fungi in the egg shell treated with air activated by the plasma-chemical reactor

\begin{tabular}{|c|c|c|}
\hline $\begin{array}{c}\text { Timing of } \\
\text { sample collection }\end{array}$ & $\begin{array}{l}\text { Modes of ozone generator } \\
\text { operation }\end{array}$ & $\begin{array}{l}\text { Species and actual level of contamination } \\
\text { (spores per } 1 \mathrm{~cm}^{3} \text { of dilution)* }\end{array}$ \\
\hline $\begin{array}{l}\text { Before treat- } \\
\text { ment, control } \\
\text { sample }\end{array}$ & 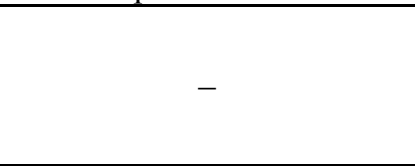 & $\begin{array}{l}\text { Rhizopus microsporus, Aspergillus fumigatus, } \\
\text { Penicillium lanosum, Trichoderma spp., } \\
\text { yeast-like fungi. } \\
\text { Contamination level }-1.550 \cdot 10^{4} \text { spores }\end{array}$ \\
\hline $\begin{array}{l}\text { Three days of } \\
\text { treatment }\end{array}$ & Discharge power $-190 \mathrm{~W} \cdot \mathrm{h}$ & $\begin{array}{l}\text { Penicillium lanosum, Rhizopus microsporus, } \\
\text { Aspergillus candidus, Rhodotorula rubra, } \\
\text { Alternaria alternata, Aspergillus proliferans. } \\
\text { Contamination level }-1.225 \cdot 10^{4} \text { spores }\end{array}$ \\
\hline $\begin{array}{l}\text { Four days of } \\
\text { treatment }\end{array}$ & Discharge power $-380 \mathrm{~W} \cdot \mathrm{h}$ & $\begin{array}{c}\text { Rhizopus microsporus, Aspergillus candidus, } \\
\text { Aspergillus fumigatus. } \\
\text { Contamination level }-0.325 \cdot 10^{4} \text { spores }\end{array}$ \\
\hline $\begin{array}{l}\text { Five days of } \\
\text { treatment }\end{array}$ & Discharge power $-570 \mathrm{~W} \cdot \mathrm{h}$ & $\begin{array}{l}\text { Penicillium lanosum, Rhizopus microsporus, } \\
\text { Rhodotorula rubra. } \\
\text { Contamination level }-0.225 \cdot 10^{4} \text { spores }\end{array}$ \\
\hline
\end{tabular}

In accordance with the results for the second stage of the experiment (see Table 4), air treatment of the egg shell significantly affected the level of contamination with microscopic fungi. Namely, the level of dissemination decreased in comparison with the control sample: after three days - by 1.26 times, after four days - by 4.8 times, and after five days - by 6.8 times. Mycobiota composition also changed. The species of Rhizopus mycrosporus, Aspergillus fumigatus, Penicillium lanosum, Trichoderma spp. and yeat-like fungi were identified in the control sample. On the fourth day of treatment, Penicillium lanosum, Rhizopus microsporus and 
Rhodotorula rubra were identified. Therefore, the treatment of the egg shell with air activated in the plasma-chemical reactor inhibited the growth not only of classic saprophytes, such as Aspergillus fumigatus, Alternaria alternata, but also of yeast-like fungi.

At the third stage of the experiment, $0.5 \mathrm{dm}^{3}$ of water was poured into the container inside the test chamber to increase the content of $\mathrm{OH}$ radicals in the active volume. The results of the study on bacterial contamination in the egg shell treated with air activated by the plasmachemical reactor with high content of $\mathrm{OH}$ radicals are presented in Table 5 .

The level of bacterial contamination in the egg shell treated with air activated by the plasma-chemical reactor with high content of $\mathrm{OH}$ radicals

\begin{tabular}{|c|c|c|}
\hline Timing of sample collection & $\begin{array}{l}\text { Operation modes of the plasma } \\
\text { chemical reactor }+\mathrm{OH} \text { radicals }\end{array}$ & $\begin{array}{l}\text { Total bacterial contamination } \\
\qquad \mathrm{CFU} / \mathrm{cm}^{3}\end{array}$ \\
\hline $\begin{array}{l}\text { Before treatment, } \\
\text { control sample }\end{array}$ & 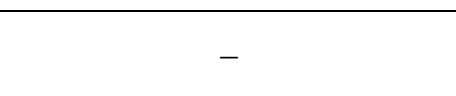 & $\begin{array}{c}\text { Enterobacter asburiae }\left(1 \cdot 10^{6}\right) \\
\text { Bacillus spp. }\left(5 \cdot 10^{6}\right)\end{array}$ \\
\hline Three days of treatment & Discharge power $-190 \mathrm{~W} \cdot \mathrm{h}$ & Bacillus spp. $\left(1 \cdot 10^{5}\right)$ \\
\hline Four days of treatment & Discharge power $-380 \mathrm{~W} \cdot \mathrm{h}$ & No growth of microorganisms \\
\hline Five days of treatment & Discharge power $-570 \mathrm{~W} \cdot \mathrm{h}$ & No growth of microorganisms \\
\hline
\end{tabular}

In accordance with the data from Table 5, the egg shell before air treatment was contaminated with such bacteria as Enterobacter asburiae $\left(1 \cdot 10^{6}\right)$ and Bacillus spp. $\left(5 \times 10^{6}\right)$. In three days after the treatment, no microorganisms of the family Enterobacteriaceae were isolated, and the level of Bacillus spp. $\left(1 \cdot 10^{5}\right)$ decreased by 50 times. The presence of Bacillus spp. is probably related to high level of humidity in the chamber.

When determining the level of contamination with microscopic fungi in the egg shell treated with air activated by the plasma chemical reactor with high content of $\mathrm{OH}$ radicals, the results presented in Table 6 were obtained.
In accordance with the experimental data (Table 6), the level of contamination with microscopic fungi decreased on days three and four by 2.25 times as a result of the egg shell treatment with air activated by the plasma-chemical reactor A significant decrease in the level of grown microscopic fungi was detected on the fifth day of treatment, which was by 7.2 times lower in comparison with the control sample.

When micromycete species were identified in the control sample, the species that are sanitary significant were distinguished.

The level of contamination with microscopic fungi in the egg shell treated with air activated

Table 6 by the plasma-chemical reactor with high content of $\mathrm{OH}$ radicals

\begin{tabular}{|c|c|c|}
\hline $\begin{array}{l}\text { Timing of sam- } \\
\text { ple collection }\end{array}$ & $\begin{array}{c}\text { Plasma chemical reactor } \\
\text { operation mode }+\mathrm{OH} \text { radicals }\end{array}$ & $\begin{array}{l}\text { Species and actual level of contamination } \\
\text { (spores per } 1 \mathrm{~cm}^{3} \text { of dilution)* }\end{array}$ \\
\hline $\begin{array}{l}\text { Before treatment, } \\
\text { control sample }\end{array}$ & - & $\begin{array}{c}\text { Aspergillus fumigatus, Penicillium lanosum, } \\
\text { Trichoderma spp., Penicillium commune, Rhizopus microspo- } \\
\text { rus, Aspergillus flavus, Aspegillus oryzae, Mucor racemosus, } \\
\text { Scopulariopsis brevicaulis, Penicillium pallidum, } \\
\text { Alternaria alternata } \\
\text { Contamination level }-1.975 \cdot 10^{4} \text { spores }\end{array}$ \\
\hline $\begin{array}{l}\text { Three days } \\
\text { of treatment }\end{array}$ & Discharge power - $190 \mathrm{~W} \cdot \mathrm{h}$ & $\begin{array}{c}\text { Alternaria alternata, Aspergillus flavus, Mucor racemosus, } \\
\text { Penicillium commune, Aspergillus fumigatus, Penicillium } \\
\text { lanosum, Trichoderma spp., Rhizopus microsporus, } \\
\text { Contamination level }-0.875 \cdot 10^{4} \text { spores }\end{array}$ \\
\hline $\begin{array}{l}\text { Four days } \\
\text { of treatment }\end{array}$ & Discharge power $-380 \mathrm{~W} \cdot \mathrm{h}$ & $\begin{array}{l}\text { Aspergillus flavus, Mucor racemosus, yeast-like fungi } \\
\text { Contamination level }-0.675 \cdot 10^{4} \text { spores }\end{array}$ \\
\hline $\begin{array}{l}\text { Five days } \\
\text { of treatment }\end{array}$ & Discharge power $-570 \mathrm{~W} \cdot \mathrm{h}$ & $\begin{array}{c}\text { Rhizopus microsporus. } \\
\text { Contamination level }-0.275 \cdot 10^{4} \text { spores }\end{array}$ \\
\hline
\end{tabular}

The following species were identified in the control sample: Aspergillus fumigatus, Penicillium lanosum, Trichoderma spp., Penicillium commune, Rhizopus microsporus, Aspergillus flavus, Aspegillus oryzae, Mucor racemosus, Scopulariopsis brevicaulis, Penicillium pallidum, Alternaria alternata. On day five, only Rhizopus microsporus was detected.

\section{CONCLUSIONS}

1. The plasma-chemical methods of surface disinfection (in particular, shell surface of hatching eggs) are the promising alternatives to the traditional chemical disinfectants.

2. In the experiment for the egg shell ozone disinfection, the total bacterial contamination was $3.6 \times 10^{5} \mathrm{CFU} / \mathrm{cm}^{3}$ on the third day of treatment, and no bacterial growth was detected on the fifth day of treatment (the control sample was $3.7 \times 10^{7} \mathrm{CFU} / \mathrm{cm}^{3}$ ). At the same time, the level of contamination with micromycetes in the egg shell was $0.300 \times 10^{4}$ spores $/ \mathrm{cm}^{3}$ of dilution after five days of treatment (the control sample was $0.775 \times 10^{4}$ spores $/ \mathrm{cm}^{3}$ ), i.e. decreased by 2.6 times. 
3. As a result of the egg shell treatment with air activated by the plasma-chemical reactor, the level of bacterial contamination decreased by 30.56 times after three days of treatment, and the complete absence of bacterial growth was detected after four days of treatment (the control sample was $1.1 \times 10^{6} \mathrm{CFU} / \mathrm{cm}^{3}$ ). Also, the level of contamination with microscopic fungi decreased by 6.9 times on the fifth day of treatment.

4. As a result of the egg shell treatment with air activated by the plasma-chemical reactor with high content of $\mathrm{OH}$ radicals, the level of contamination with bacteria and micromycetes decreased even more significantly. On the third day of treatment, the level of bacterial contamination decreased by 60 times, and on the fifth day of treatment, the level of contamination with microscopic fungi decreased by 7.2 times.

\section{REFERENCES}

1. L.S. Polak, A.A. Ovsyannikov, D.I. Slovetsky. Theoretical and applied plasma chemistry. M.: "Nauka", 1975, $304 \mathrm{p}$.

2. F.Mc. Taggart. Plasmochemical reactions in electrical discharges. M.: "Atomizdat", 1972, 256 p.

3. V.I. Golota, G.V. Taran, A.A. Zamuriev, P.O. Opalev, S.G. Pugach, S.N. Mankovskyi, V.P. Petrenkova, I.N. Nyska. The use of ozone technologies in grain storage // Problems of Atomic Science and Technology. Series "Plasma Electronics and New Methods of Acceleration”. 2018, № 4, p. 185-188.

4. A.M. Holdoenko. Epizootological supervision in industrial poultry // Abstract of PhD Thesis - Nizhny Novgorod. 2002, 24 p.

5. V.I. Bilay, N.M. Pidoplichko. Toxin-forming microscopic fungi and diseases they cause to man and animals. Kyiv: "Naukova Dumka", 1970, 291 p.
6. O. Sutton, A. Fothergill, M. Rinaldi. Determinant of pathogenic and opportunistic fungi / Ed. D.G. Zvyagintsev. M.: "Mir", 2001, 487 p.

7. S.V. Abraskova, Yu.K. Shashko, M.N. Shashko. Biological safety of feeds. Minsk: "Belaruskaya Navuka", 2013, 257 p.

8. T.Ya. Phakadze. The activity of antiseptics and disinfectants against different species of nonfermentative gram-negative bacteria // Laboratory science. 1991, p. 58-61.

9. Y. Ali, M.J. Dolan, E.J. Fendler, E.L. Larson. Alcohols. Disinfection, sterilization and preservation / Block S.S. (Ed.) New York: Lippincott Williams \& Wilkins, 2001, p. 229-255.

10. Disinfectants. Guideline. Trading company "Bingo Grand". Moscow, 2008.

11. L.S. Fedorova, L.I. Arefieva, L.S. Putintseva, N.A. Veromkovich. Modern means of disinfection and disinsection. Characteristic, appointment, prospects. M.: "Soyuzmedinform", 1991.

12. S.M. Kabardiev, K.G. Amaev, M.A. Baktemirov. Bactericidal and disinfectant properties of new environmentally-friendly drugs // Problems of veterinary sanitation, hygiene and ecology. M.: 1999, p. 51-52.

13. O.K. Pozdeev, R.V. Fedorov. Enterobacteria [Guide for Physicians] Moscow: GEOTAR-Media, 2007, p. 720 .

14. A.S. Labinskaya, L.P. Blinkova, A.S. Eschina. Private medical microbiology with technique of microbiological researches. M.: "Meditsina", 2005, 600 p.

15. I. Family. Enterobacteriaceae. Vol. 2, Part B. The Gamma proteobacteria. Bergeys Manual of Systematic Bacteriology / George M. Garrity, Editor-inChief, Bergeys Manual Trust // Springer, 2005, p. $587-850$.

Article received 29.05.2019

\section{ПЛАЗМОХИМИЧЕСКИЕ МЕТОДЫ КОНТРОЛЯ КОНТАМИНАНТОВ БИОТИЧЕСКОГО ПРОИСХОЖДЕНИЯ}

\section{Г.В. Таран, В.А. Бреславещ, А.А. Замуриев, М.О. Ярошенко, П.О. Опалев, О.В. Майборода}

Экспериментально исследованы возможность и эффективность контроля контаминантов биотического происхождения (бактерии, микромицеты) озоном и воздухом, обработанным в плазмохимическом разряде, на модели инкубационных яиц как альтернатива химическим методам обработки. Показано, что обработка поверхности яиц озоном снизила бактериальную загрязненность в 3083 раза после четырех суток обработки, а количество микробиоты - в 2,6 раза после пяти суток обработки. Обработка поверхности яиц воздухом, активированным в плазмохимическом разряде, повлияла на уменьшение в 30,56 раза бактериальной загрязненности после трех суток обработки и уменьшение степени контаминации микроскопическими грибами на пятые сутки в 6,9 раза. При повышении количества радикалов ОН в активированном воздухе уровень бактериальной культуры уменьшился в 60 раз на третьи сутки, а степень контаминации поверхности скорлупы яиц микроскопическими грибами снизилась в 7,2 раза на пятые сутки.

\section{ПЛАЗМОХІМІЧНІ МЕТОДИ КОНТРОЛЮ КОНТАМІНАНТІВ БІОТИЧНОГО ПОХОДЖЕННЯ}

\section{Г.В. Таран, В.О. Бреславець, О.О. Замурієб, М.О. Ярошенко, П.О. Опалєв, О.В. Майборода}

Експериментально досліджено можливість і ефективність контролю контамінантів біотичного походження (бактерії, мікроміцети) озоном та повітрям, яке оброблено у плазмохімічному розряді, на моделі інкубаційних яєць, що може бути альтернативою хімічним методам обробки. Показано, що обробка поверхні яєць озоном знизила бактеріальну забрудненість в 3083 рази після чотирьох діб обробки, а кількість мікробіоти - в 2,6 раза після п'яти діб обробки. Обробка поверхні яєць повітрям, що активоване у плазмохімічному розряді, вплинула на зменшення бактеріальної забрудненості в 30,56 раза після трьох діб обробки та зменшила ступінь контамінації мікроскопічними грибами на п’яту добу в 6,9 раза. При підвищенні кількості радикалів ОН в активованому повітрі рівень бактеріальної культури зменшився в 60 разів на третю добу, а ступінь контамінації поверхні шкаралупи яєць мікроскопічними грибами знизився в 7,2 раза на п'яту добу. 